\title{
POPULASI DAN TINGKAT PEMANFAATAN BULU BABI (Echinoidea) DI PADANG LAMUN PULAU OSI, SERAM BARAT, MALUKU TENGAH
}

\author{
Amran Ronny Syam"), Isa Nagib Edrus"), dan Retno Andamari")
}

\begin{abstract}
ABSTRAK
Penelitian populasi bulu babi dan pemanfaatannya di perairan padang lamun Pulau Osi telah dilakukan pada bulan Juni 1995 sampai dengan Februari 1996. Metode transek kuadrat digunakan untuk menduga kepadatan populasi bulu babi tersebut. Indeks agregasi digunakan sebagai indikator dari sifat distribusi spasial populasi itu. Hasil penelitian menunjukkan, bahwa dari sembilan jenis bulu babi yang dijumpai di perairan tersebut hanya Tripneustes gratilla saja yang bernilai ekonomis, banyak dijumpai dan dimanfaatkan oleh penduduk setempat. Kepadatan jenis tersebut $0,754 \pm 0,152$ individu $/ \mathrm{m}^{2}$. Distribusi spasial populasi $T$. gratilla dan Diadema setosum bersifat mengelompok, lima jenis (Mespilia globulus, Echinometra mathai, Pseudolobotia maculata, Taxopneustes pileolus, dan Salmacis sp) bersifat merata, dan dua jenis lainnya (Diadema sp dan Echinotrix calamaris) bersifat acak. Penangkapan bulu babi biasanya dilakukan pada musim timur dengan puncaknya diduga pada bulan Agustus sampai dengan Oktober.
\end{abstract}

\section{ABSTRACT: Sea urchin population (Echinoidea) and their exploitation on the seagrass beds of Osi Island waters, Central Moluccas. By: Amran Ronny Syam, Isa Nagib Edrus and Retno Andamari}

\begin{abstract}
A study of sea urchin population and its exploitation on the seagrass beds of Osi Island waters was carried out from June 1995 to February 1996. Quadratic transect method was used in this study to determine population density. The aggregation index was used as indicator for the spatial distribution of the population. Results showed that among nine species of sea urchins found in this area, only Tripneustes gratilla has economic value and was exploited by the local people. The density of this economic valuable species in the study area was about $0.754 \pm 0.152$ individual $/ m^{2}$. The spatial distribution pattems were: clumped for T. gratilla and Diadema setosum; uniform for five species (Mespilia globulus, Echinometra mathai, Pseudolobotia maculata, Taxopneustes pileolus, and Salmacis sp); and random for two others (Diadema $s p$ and Echinotrix calamaris). Sea urchins were exploited during the east monsoon especially from August to October.
\end{abstract}

KEYWORDS: $\quad$ sea urchin density, spatial distribution and exploitation, Central Moluccas.

\section{PENDAHULUAN}

Padang lamun (seagrass beds) di kawasan Teluk Kotania Seram Barat (termasuk Pulau Osi) merupakan habitat potensial sebagai lahan budi daya laut. Selain itu daerah tersebut banyak terdapat hutan bakau dan terumbu karang. Berbagai macam komoditas ekonomis penting dijumpai di padang lamun tersebut; di antaranya adalah kekerangan, teripang, rumput laut, ikanikan lamun, dan yang terakhir mendapat perhatian adalah bulu babi (Naamin et al., 1995).

Bulu babi memiliki nilai niaga karena telurnya merupakan produk perikanan yang dapat dikonsumsi secara segar dan diolah sebagai bahan makanan yang bergizi. Di Maluku belum dipasarkan secara komersial (Andamari et al., 1996). Beberapa negara tropis mengekspor telur bulu babi ke Jepang dalam bentuk segar, produk bahan mentah maupun olahan melalui pengalengan dan pengasapan (Conand \& Sloan, 1989). Di Jepang, telur bulu babi biasanya diawetkan dengan garam atau alkohol, kemudian disimpan selama satu bulan sebelum dikonsumsi (Shimada \& Ogura, 1990). Telur bulu babi memiliki kadar protein yang hampir sama dengan protein daging kekerangan (Andamari et al.,1996; Pigott \& Tucker, 1989; Nontji, 1987). Ekspor komoditi tersebut di Indonesia belum banyak dilakukan. Di Bali pada tahun 1985 bulu babi telah diekspor sekitar 1,1 ton atau senilai 2.900 US \$ (Darsono \& Sukarno, 1993).

Untuk kepentingan pengelolaan sumber dayanya, beberapa penelitian tentang aspek populasi, biologi, dan reproduksi bulu babi pernah dilakukan oleh Darsono \& Sukarno (1993) di perairan lamun Nusa Dua Bali dan oleh Andamari et al. (1994) di perairan lamun Banda Neira. Data

\footnotetext{
"Peneliti pada Balai Pengkajian Teknologi Pertanian Maluku, Ambon
} 
dan informasi mengenai aspek yang sama untuk berbagai lokasi di Indonesia masih sangat kurang, sementara pemanfaatannya secara tradisional di pesisir pantai terus meningkat. Bulu babi adalah fauna bentik yang paling mudah ditangkap. Apabila pemanfaatannya tidak dilakukan secara seimbang dan lestari, besar kemungkinan terjadi kelebihan tangkap (over exploitation). Banyak lokasi yang sebelumnya dikenal sebagai daerah penangkapan lumbung bulu babi jenis tertentu, tetapi pada saat sekarang sudah tidak demikian lagi.

Mengingat pentingnya bulu babi untuk perikanan secara umum, maka penelitian aspek populasi dan pemanfaatan sumber daya perlu dilakukan. Penelitian ini bertujuan untuk mendapatkan data potensi, jenis, ukuran, sebaran populasi dan tingkat pemanfaatan bulu babi di Pulau Osi.

\section{BAHAN DAN METODE}

\section{Waktu dan Daerah Penelitian}

Penelitian dilakukan pada bulan Juni 1995 sampai bulan Februari 1996 di sekitar perairan Pulau Osi (Gambar 1), yang merupakan bagian dari Teluk Kotania (Kecamatan Seram Barat, Kabupaten Maluku Tengah). Sebagian besar perairan dangkal (daerah pasang surut) Teluk Kotania ditumbuhi vegetasi lamun. Vegetasi pada lokasi tersebut didominasi oleh jenis Thallasia hemprichii, Enhalus acaroides dan Cymodocea ciliata. Menurut hasil survei MREP, padang lamun di Teluk Kotania masih dalam kondisi baik. Ketiga jenis vegetasi itu menutupi hampir $80 \%$ wilayah padang lamun (Naamin et al, 1995).

\section{Metode Penelitian}

Metode yang digunakan dalam penentuan tingkat kepadatan dan distribusi spasial adalah transek kuadrat (Krebs, 1989; Odum, 1971). Luasan daerah contoh adalah $100 \times 100 \mathrm{~m}^{2}$ (1 ha) pada hamparan padang lamun yang berjarak sekitar 100 m dari pantai Pulau Osi. Sampling kuadrat dilakukan secara horizontal terhadap garis pantai pada saat surut hingga menjelang pasang dengan kedalaman air antara 0 sampai $75 \mathrm{~cm}$. Sebanyak 60 petak kuadrat (ukuran $1 \times 1 \mathrm{~m}^{2}$ ) diplot setiap bulan (Juni 1995 sampai Februari 1996) terhadap jenis bulu babi yang bernilai ekonomis dan dominan dijumpai. Selain itu dilakukan juga pengukuran diameter cangkang

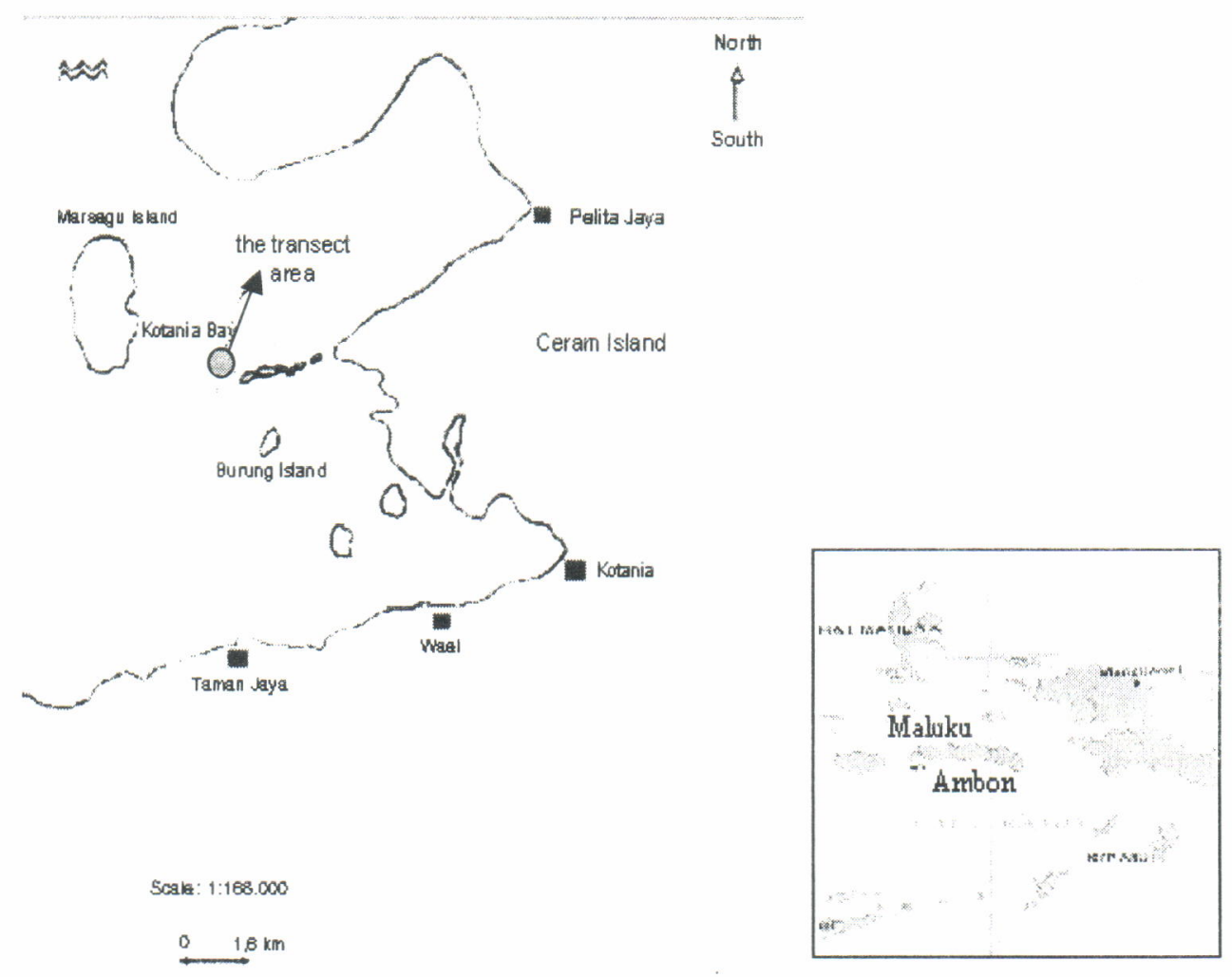

Gambar 1. Daerah transek bulu babi di padang lamun P.Osi, Maluku Tengah.

Figure 1. The transect area of sea urchin on the seagrass beds of Osi Island, Central Moluccas. 
(ambitus dalam) untuk mengetahui kelimpahan dan ukuran pada musim tersebut. Identifikasi jenis bulu babi dilakukan sesuai buku petunjuk Allen \& Steene (1994).

Kepadatan rata-rata per $\mathrm{m}^{2}$ adalah $\bar{X}=\sum_{i=1}^{n} X_{i} / \mathrm{N}$ Ragam dari $x$ atau $s^{2}=\frac{\sum x^{2}-\left(\sum X\right)^{2}}{N-1}$.

Kepadatan rata-rata per $\mathrm{m}^{2}$ pada selang kepercayaan $95 \%$ adalah $\mathrm{x} \pm \mathrm{t}(\mathrm{S} / \mathrm{V} \mathrm{n})$ di mana:

$x$ : jumlah individu tiap kuadrat number of individual per frame),

$n$ : total individu yang terdapat dalam seluruh kuadrat (total individual for all frames),

$N$ : jumlah total kuadrat (total number of frame)

t : nilai tabel distribusi-t untuk selang kepercayaan $P=0,05$ dengan derajat bebas $n-1$ (value of student distribution on the 5 per cent confidence level significantly with degrees of freedom $n-1)$

$S^{2}$ : ragam dari $x$ (the variance of $x$ ).

$S$ : simpangan baku dari $x$ (the standard deviation of $x$ )

Kelimpahan sumber daya per $100 \mathrm{~m}^{2}$ dihitung berdasarkan hasil interpolasi kepadatan per $\mathrm{m}^{2}$. Pola sebaran populasi dianalisis dengan pendekatan indeks agregasi (I) Odum (1971), di mana nilai (I) merupakan perbandingan antara ragam $\mathrm{S}^{2}$ (variance) dengan kepadatan individu rata-rata per $\mathrm{m}^{2}(\bar{X})$. Menurut Odum, 1971 apabila nilai $1=1$ berarti pola sebaran individu bersifat acak (random distribution); apabila $1<1$ maka pola sebaran merata (uniform distribution); dan apabila I $>1$, pola sebaran bersifat mengelompok (clumped distribution).

Kepadatan populasi bulu babi yang potensial, diamati setiap bulan dari Juni 1995 sampai dengan Februari 1996 untuk mengetahui fluktuasi kepadatan populasi.

\section{HASIL DAN BAHASAN}

\section{Jenis, Kepadatan, dan Sebaran Spasial}

Di daerah penelitian terdapat sembilan jenis bulu babi sebagai penghuni padang lamun termasuk dalam kelas Echinoidea (Tabel 1). Bulu babi hitam (Diadema spp.) cenderung menyebar luas di sekitar Pulau Osi, populasinya selalu dijumpai di berbagai lokasi dan habitat, baik karang pasir maupun lamun. Pada umumnya telur bulu babi hitam tidak dikonsumsi masyarakat di Maluku, karena selain ukurannya yang kecil, durinya juga berbisa sehingga menyulitkan penangkapan dan pengolahannya.

Jenis bulu babi lain yang memiliki duri berbisa adalah Echinometra mathaei. Jenis ini telurnya juga belum diekploitasi untuk bahan makanan dan lebih berperan sebagai bahan hiasan akuarium. Dalam perdagangan, jenis ini dikenal dengan nama landak laut, cangkang sangat kecil dengan duri yang panjang seperti landak. Secara umum, jenis ini terlihat cantik sebagai hiasan. Kepadatannya di Pulau Osi tergolong rendah, yaitu $0,04 \pm 0,01$ individu/ $100 \mathrm{~m}^{2}$

Tabel 1. Kepadatan rata-rata, keragaman dan indeks distribusi spasial populasi bulu babi di perairan padang lamun Pulau Osi

Table 1. Mean, variance, and spatial distribution index of sea urchin on the seagrass beds of Osi Island waters

\begin{tabular}{lcccc}
\hline \multicolumn{1}{c}{$\begin{array}{c}\text { Jenis } \\
\text { Species }\end{array}$} & $\bar{X}$ & $\mathrm{~s}^{2}$ & $\mathbf{s}^{2} / \bar{X}$ & $\begin{array}{c}\text { Keterangan } \\
\text { Remarks }\end{array}$ \\
\hline Tripneustes gratilla & 0.754 & 1.128 & 1.496 & mengelompok (clumped distribution) \\
Diadema setosum & 0.4 & 0.568 & 1.42 & mengelompok (clumped distribution) \\
Mespilia globulus & 11.6 & 10.8 & 0.931 & acak (uniform distribution) \\
Echinometra mathai & 0.0004 & 0.0004 & 1 & acak (random distribution) \\
Pseudolobotia maculata & 0.0005 & 0.0005 & 1 & acak (random distribution \\
Taxopneustes pileolus & 0.0005 & 0.0005 & 1 & acak (random distribution \\
Salmacis sp & 0.0005 & 0.0005 & 1 & acak (random distribution \\
Diadema sp & 0.0005 & 0.0000 & 0 & merata (uniform distribution) \\
Echinotrix calamaris & 0.0005 & 0.0000 & 0 & merata (uniform distribution) \\
\hline
\end{tabular}

Catatan/Notes: $\bar{X}$ : kepadatan rata-rata/mean density (individual $/ \mathrm{m}^{2}$ ); $\mathrm{s}^{2}$ : varian/variance $\mathrm{S}^{2}$ varian rasio rata-rata/variance-mean ratio 
Jenis bulu babi yang memiliki kepadatan tinggi tetapi telurnya tidak diusahakan adalah seroa kerdil (Mespilia globulus). Kepadatan di Pulau Osi adalah 11,6 $\pm 0,86$ individu $/ \mathrm{m}^{2}$. Jenis ini durinya tidak berbisa dan tubuhnya tergolong kecil. Diameter cangkang terbesar yang ditemukan adalah $50 \mathrm{~mm}$. Tubuhnya yang kerdil inilah yang menyebabkan nelayan tidak memanfaatkan telurnya. Bulu babi yang memiliki ukuran cangkang dengan telur yang besar dapat ditemukan pada jenis Pseudolobotia maculata, Taxopneustes pileolus, Salmacis spp, dan T. gratilla. Ketiga jenis pertama dari empat jenis bulu babi tersebut kepadatannya rendah $(0,05 \pm 0,01$ individu/100 $\left.\mathrm{m}^{2}\right)$; sedangkan jenis yang terakhir disebutkan kepadatannya lebih tinggi yaitu $0-5$ individu $/ \mathrm{m}^{2}$ dengan kepadatan rata-rata $0,754 \pm 0,152$ individu/ $\mathrm{m}^{2}$. Kepadatan individu rata-rata $T$. gratilla yang dijumpai di perairan Nusa Dua (Bali) dan Banda Naira (Maluku Tengah) masing-masing adalah 0,278 individu $/ \mathrm{m}^{2}$ (Darsono \& Sukarno 1993) dan 2,83 individu/ $\mathrm{m}^{2}$ (Andamari et al., 1994). Dengan demikian, kepadatan bulu babi $T$. gratilla di perairan Pulau Osi (Maluku Tengah) lebih tinggi dari pada di perairan Nusa Dua (Bali); tetapi lebih rendah dari pada di perairan Banda Naira (Maluku Tengah)

Tingginya kepadatan $T$. gratilla dan Mespilia globulus yang dijumpai di perairan Pulau Osi, diasumsikan berpengaruh terhadap perkembangan ukuran populasi bulu babi yang lain, seperti Pseudolobotia maculata, Salmacis spp., dan Taxopneustes pileolus. Hal ini mungkin disebabkan oleh adanya kompetisi antar populasi, terutama menyangkut daerah penyebaran.

Kelimpahan populasi bulu babi $T$. gratilla setiap bulan di Pulau Osi menunjukkan adanya penurunan (Tabel 2).

Tabel 2. Deskripsi ukuran dan kepadatan bulu babi ( $T$. gratilla) di perairan padang lamun Pulau Osi Table 2. Size description and density of sea urchin ( $\mathrm{T}$. gratilla) on the seagrass beds of Osi Island waters

\begin{tabular}{|c|c|c|c|c|}
\hline \multirow{2}{*}{$\begin{array}{l}\text { Bulan } \\
\text { (Month) }\end{array}$} & \multirow{2}{*}{$\begin{array}{l}\text { Jumlah sampel } \\
\text { (Number of } \\
\text { samples) }\end{array}$} & \multicolumn{2}{|c|}{$\begin{array}{c}\text { Ukuran } \\
\text { (Size) }\end{array}$} & \multirow{2}{*}{$\begin{array}{c}\begin{array}{c}\text { Kepadatan } \\
(\text { Density) }\end{array} \\
\left.\text { individu / }(100 \mathrm{~m})^{2}\right] \\
{\left[\text { individual } /(100 \mathrm{~m})^{2}\right]}\end{array}$} \\
\hline & & $\begin{array}{l}\text { Selang panjang }(\mathrm{mm}) \\
(\text { Ranges }(\mathrm{mm}))\end{array}$ & $\begin{array}{l}\text { Rata-rata }(\mathrm{mm}) \\
(\text { Average }(\mathrm{mm}))\end{array}$ & \\
\hline Jun-95 & 131 & $37,6-65,2$ & 51,52 & 7,540 \\
\hline Juli 1995 & 164 & $32,5-71,3$ & 49,19 & 7,500 \\
\hline Aug-95 & 92 & $41,9-69,5$ & 51,24 & 12,170 \\
\hline Sep-95 & 55 & $46,5-65,0$ & 56,17 & 8,830 \\
\hline Oct-95 & 80 & $48,5-80,0$ & 60,18 & 7,670 \\
\hline Nov-95 & 138 & $39,5-81,0$ & 59,29 & 4,000 \\
\hline Dec-95 & 60 & $51,5-73,0$ & 60,86 & 2,500 \\
\hline Jan-96 & 80 & $49,6-78,5$ & 59,04 & 1,000 \\
\hline Feb-96 & 71 & $50,2-68,4$ & 58,23 & 96,000 \\
\hline Total & 871 & & & \\
\hline Average & & & 56,19 & \\
\hline
\end{tabular}

Penurunan ini diduga disebabkan oleh musim atau predator, sebab pada saat penelitian dilakukan tidak ada usaha penangkapan di daerah transek, selain tidak ada bukti-bukti yang menunjukkan migrasi karena pengaruh musim. Pada saat pengamatan sering terlihat bintang laut yang sedang memangsa bulu babi dengan demikian pemangsaan predator terhadap bulu babi cenderung mendekati dugaan.

Hasil analisis perbandingan keragaman kepadatan individu bulu babi $\mathrm{S}^{2}$ dengan kepadatan rata-ratanya $(\bar{X})$ menunjukkan bahwa sebaran populasi $T$. gratilla dan $D$. setosum bersifat mengelompok. Dari nilai indeks tersebut diduga bahwa bulu babi jenis $T$. gratilla mempunyai perilaku yang cenderung untuk beragregasi di dalam populasinya, seperti terlihat secara visual di alam yang cenderung berkelompok. Hal yang sama juga didapatkan oleh Andamari et al. (1994) di Banda Naira.

Populasi lima jenis (M. globulus, E. mathai, $P$ maculata, $T$. pileolus, dan Salmacis $\mathrm{sp}$ ) cenderung memiliki distribusi acak (random distribution). Distribusi populasi dua jenis bulu babi lainnya (Diadema sp dan Echinotrix calamaris) dikategorikan merata (uniform distribution). Rasio keragaman bulu babi dengan kepadatan rataratanya disajikan dalam Tabel 1 


\section{Musim dan Pemanfaatan}

Populasi bulu babi jenis $T$. gratilla (Gambar 2) paling banyak dijumpai pada musim angin timur antara Mei sampai Nopember (nelayan setempat, komunikasi langsung). Jenis bulu babi tersebut dikonsumsi dalam bentuk segar maupun olahan.

Di luar areal penelitian bulu babi ditangkap secara intensif oleh penduduk setempat selama periode air surut pada sore hari. Pada periode itulah umumnya bulu babi keluar dari sela-sela padang lamun untuk mencari makan dengan memanjat daun-daun lamun sehingga mereka mudah terlihat. Tingkah laku semacam inilah yang menyebabkan populasi bulu babi mudah tertangkap.

Penangkapan bulu babi sebagian besar dilakukan untuk kepentingan konsumsi lokal dan hanya sebagian kecil saja yang dijual ke pasar Piru. Telur bulu babi yang diambil dari lima individu, dikemas dalam sebuah cangkang bulu babi yang berukuran besar dan dijual seharga Rp 500,-lekor.

Pada musim angin barat, populasi bulu babi menurun dan meningkat kembali ketika musim angin timur. Hal ini dapat dilihat pada Tabel 2 yang menunjukkan kelimpahan $T$. gratilla yang cenderung menurun pada akhir musim timur. Fenomena ini sesuai dengan sinyalemen Odum (1971) yang secara umum menyatakan bahwa pada semua ekosistem ada kecenderungan yang kuat untuk semua populasi berkembang melalui seleksi alam ke arah pengaturan diri sendiri (karena kelebihan populasi tidak memperhatikan kepentingan beberapa populasi lain), sekalipun hal ini sulit untuk dicapai di bawah tekanan ekstrinsik, yakni interaksi populasi dengan lingkungan luar, seperti misalnya perbedaan lingkungan fisik populasi tahunan yang menyebabkan adanya fluktuasi ukuran populasi. Lebih lanjut dinyatakan bahwa faktor iklim, dalam berbagai kejadian berperan dan menentukan ukuran kepadatan suatu populasi (Odum, 1971). Dalam penelitian ini faktor musim sangat berpengaruh terhadap kepadatan populasi di perairan Pulau Osi.

Penyebab menurunnya populaşi bulu babi di alam, faktor recruitment overfishing (banyak individu-individu yang matang gonad ditangkap) tidak dapat diabaikan (Andamari et al., 1994; Darsono \& Sukarno, 1993). Pemantauan penangkapan, studi dinamika populasi bulu babi perlu dilakukan untuk mengetahui apakah penurunan populasi dari habitatnya merupakan akibat dari growth overfishing (individu-individu muda yang tumbuh banyak tertangkap) atau recruitment overfishing atau keduanya.

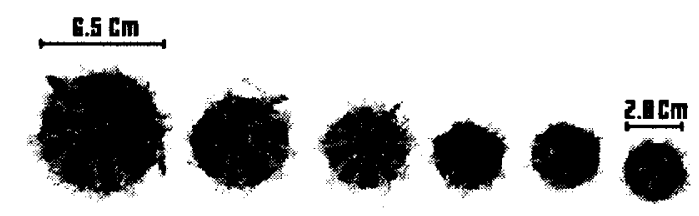

Gambar 2. Jenis bulu babi ekonomis penting ( $T$. gratilla) yang dijumpai di padang lamun Perairan Pulau Osi.

Figure 2. The most important species of sea urchin (T. gratilla) found in sea grass beds of Osi Island waters.

Laju tangkap bulu babi jenis $T$. gratilla yang diamati selama 5 jam trip penangkapan di Pulau Osi yang dilakukan oleh 51 orang, diperoleh hasil sebanyak 5.083 individu. Hal ini berarti bahwa rata-rata tangkapan per unit upaya (catch per unit effort, CPUE) adalah $20 \pm 13$ individu/orang/jam. Berdasarkan pengamatan luas areal padang lamun di Pulau Osi sebesar $60.000 \mathrm{~m}^{2}$ dan kelimpahan sumber daya 75.40 individu/100 $\mathrm{m}^{2}$, maka sediaan sumber daya bulu babi jenis $T$. gratilla pada saat itu sebesar 45.240 individu. Dari hasil perhitungan ini diperoleh gambaran bahwa sumber daya bulu babi tersebut dapat habis hanya dalam sembilan trip penangkapan. Dengan demikian tingkat pemanfaatan sumber daya bulu babi jenis $T$. gratilla di Pulau Osi dianggap cukup tinggi tetapi pada kenyataannya menurut nelayan setempat masih terdapat populasi yang melimpah pada periode berikutnya. Hal ini dapat disebabkan oleh terbatasnya musim penangkapan atau 
adanya lokasi penangkapan yang lain, sehingga tidak terpusat pada satu daerah penangkapan saja, akhirnya dapat memungkinkan pulihnya sumber daya bulu babi tersebut pada musim berikutnya. Fenomena ini didukung oleh fakta bahwa di sekitar Pulau Osi di luar areal transek banyak terdapat induk-induk $T$. gratilla yang cukup jauh dari daerah pemukiman sehingga jarang ditangkap oleh penduduk setempat. Diduga rekruitmen berasal dari daerah ini. Bulu babi mempunyai fekunditas kurang lebih 1,1 juta butirlekor dan dapat mencapai matang gonad (dewasa) pada umur 1,5 tahun (Tuwo \& Tresnati, 1995), yang dapat memproduksi bulu babi muda tumbuh menjadi bulu babi dewasa sebagai populasi baru.

Informasi tentang reproduksi dan mortalitas akan sangat membantu dalam mengetahui besarnya penambahan individu-individu baru terhadap populasinya dalam satuan waktu. Untuk membuktikan apakah memang terjadi pergantian massa dalam populasi bulu babi pada musim selanjutnya dapat dianalisa dari munculnya kelompok-kelompok umur ganda dalam satu populasi. Mengenai selang waktunya masih perlu diteliti lebih lanjut.

Hubungan antara diameter cangkang rata-rata dengan kelimpahan bulu babi $T$. gratilla (individu/100 $\mathrm{m}^{2}$ ) di perairan Pulau Osi yang dipantau setiap bulan pada periode Juni 1995 stampai dengan Februari 1996 disajikan pada Gambar 3.

Pada gambar tersebut, ukuran diameter cangkang rata-rata bulu babi cenderung bertambah pada bulan Agustus 1995 dan semakin stabil pada bulan Oktober 1995 hingga Februari 1996. Sebaliknya kelimpahan individu tiap $100 \mathrm{~m}^{2}$, cenderung meningkat hingga bulan Agustus dan menurun pada bulan September 1995 hingga Februari 1996. Pola kurva tersebut menunjukan adanya kecenderungan ukuran rata-rata bulu babi lebih kecil pada bulan sebelumnya. Hal ini dapat dibandingkan dengan hasil pengamatan Andamari et al. (1994) bahwa ukuran diameter rata-rata T. gratilla yang dijumpai di Perairan Banda Naira pada Bulan April adalah 44,7 mm.

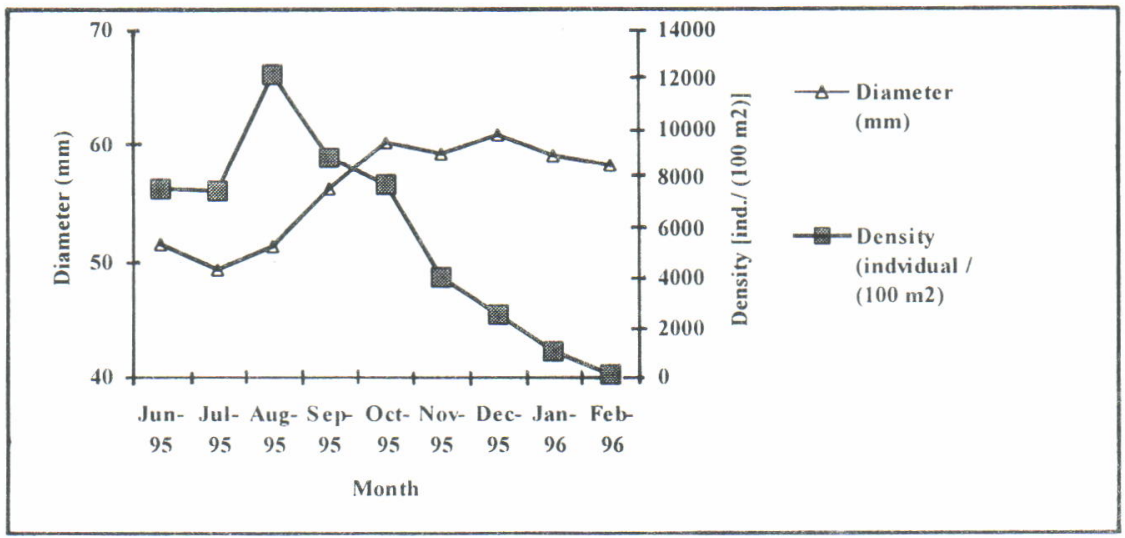

Gambar 3. Ukuran diameter dan kepadatan bulu babi ( $T$. gratilla) di perairanpadang lamun Pulau Osi.

Figure 3. Size diameter and density of sea urchin ( $T$. gratilla) on the seagrass beds of Osi Island waters.

Bulu babi jenis $T$. gratilla yang memiliki gonad (telur) yang besar berukuran diameter cangkang rata-rata $50 \mathrm{~mm}$. (Andamari et al., 1996). Jika pemanenan bulu babi jenis tersebut di Pulau Osi yang dilakukan pada ukuran lebih dari $50 \mathrm{~mm}$, maka hal ini dapat memberikan kesempatan bagi populasi tersebut untuk memijah sehingga recruitment overfishing kemungkinan dapat dihindari.

Dari pengamatan bulu babi di Pulau Osi dan informasi dari penduduk setempat dapat dikatakan bahwa pada musim timur banyak dijumpai populasi bulu babi terutama jenis $T$. gratilla dan optimalnya pada bulan Agustus sampai dengan Oktober.

\section{KESIMPULAN DAN SARAN}

\section{Kesimpulan}

1. Dari sembilan jenis bulu babi yang dijumpai di perairan padang lamun Pulau Osi, hanya jenis T. gratilla yang bernilai ekonomis dan banyak dimanfaatkan oleh masyarakat setempat. Kepadatan rata-rata bulu babi tersebut 0,754 individu $/ \mathrm{m}^{2}$, atau kelimpahannya sebesar 7.540 individu per ha.

2. Kelimpahan bulu babi $T$. gratilla menurun seiring dengan berakhirnya musim timur. 
3. Distribusi populasi $T$. gratilla dan D.setosum bersifat mengelompok, sedang jenis lainnya cenderung bersifat acak atau merata.

4. Penangkapan bulu babi $T$. gratilla secara intensif cenderung dilakukan oleh penduduk Pulau Osi dan sekitarnya pada musim timur.

\section{Saran}

1. Perlu pemantauan migrasi bulu babi jenis $T$. gratilla untuk mengetahui penurunan kepadatan populasi tersebut pada akhir musim timur.

2. Perlu pengamatan pengaruh predator terhadap kepadatan populasi bulu babi, pola reproduksi, terutama rekruitmen dan daerah pemijahan.

\section{DAFTAR PUSTAKA}

Allen, G.R. \& R.Steene. 1994. Indo Pacific coral reef. field guide. Tropical Reef Research, Singapore. $378 \mathrm{hal}$.

Andamari, R., E. Chasanah, A.R. Syam, \& I.N. Edrus. 1996. Pemanfaatan sumber daya bulu babi melalui uji coba pembesaran dan pasca panennya. Balai Pengkajian Teknologi Pertanian Ambon.

Andamari, R., T. Zubaidi, \& Subagyo. 1994. Beberapa aspek biologi bulu babi Tripneustes spp. di Pulau Neira, Kepulauan Banda. Jurnal Penelitian Perikanan Laut, Balai Penelitian Perikanan Laut, Jakarta,94: 23 - 34.

Conand, C. \& N.A.Sloan. 1989. World fisheries for echinoderms. In: Caddy,J.F. Eds., Marine
Invertebrate Fisheries: Their Assessment and Management. John Wiley \& Sons, New York. Hal: 647 - 663.

Darsono, P. \& Sukarno. 1993. Beberapa aspek biologi bulu babi, Tripneustes gratilla (Linnaeus), di Nusa Dua - Bali. Oseanologi di Indonesia, 26: 13 - 25.

Krebs, C.J. 1989. Ecological methodology. Harper \& Row. Pub., New York. 654 hal.

Naamin, N., H.E.Irianto, V.Nikijuluw, S.Nurhakim \& Budiharjo. 1995. Survei perikanan dan sosial ekonomi di MCMA Maluku. Marine Resource Evaluation and Planning Project (MREP), Jakarta.

Nontji, A. 1987. Laut Nusantara. Penerbit Djambatan. Jakarta. 368 hal.

Odum, E.P. 1971. Fundamental of ecology. 3rd ed. W.B. Saunders Company. Philadelphia. 574 hal.

Pigott, G.M. \& B.W. Tucker. 1989. Seafood: effect of technology on nutrition. Marcel Dekker. Inc. New York and Basel 33 hal.

Shimada, K. \& N. Ogura. 1990. Lipid changes in sea urchin gonads during storage. Journal of Food Science, 55 (4): 967 - 971.

Tuwo, A. \& J. Tresnati. 1995. Studi pendahuluan aspek biologi bulu babi Diadema setosum dan Tripneustes gratilla di kepulauan Spermonde, Sulawesi Selatan. Prosiding Seminar Kelautan Nasional-1995. Panitia Pengembangan Riset dan Teknologi Kelautan Serta Industri Maritim. 
